\title{
The Spatial Patterns and Local Economic Determinant of Industrial Agglomeration in Semarang District, Indonesia
}

\author{
R. A. Pangarso ${ }^{a^{*}}$, R. Suharyadi ${ }^{a}$, R. Rijanta ${ }^{a}$ \\ ${ }^{a}$ Geography Faculty, Gadjah Mada University, Indonesia
}

\section{Article Info:}

Received: 2 August 2017 in revised form: 2 October 2017

Accepted: 2 December 2017

Available Online: 30 December 2019

\section{Keywords:}

Industrial agglomeration; spatial pattern; local economy.

*Corresponding Author:

R. Agung Pangarso

Geography Faculty, Gadjah Mada

University, Indonesia

Email: pangarso@gmail.com

\begin{abstract}
Urbanization and industrialization are actual phenomena in metropolitan cities, including Semarang District, a part of Semarang Metropolitan. On the other hand, this district is still facing economic problems such as unequal income and unemployment. In this context, it is interesting to identify the linkage between industrial agglomeration and the local economy. This research aims: to identify the spatial patterns of industrial agglomeration; and to identify the main factors of the local economy and how do they determine the industrial agglomeration. The research was done at the district and subdistrict levels from January to July 2017. It uses variables of geographical data and workers of Large and Medium Industries (LMIs) and the local economy. Nearest Neighbor Analysis, Ellison-Glaeser Index, and Specialization Index are used to analyze industrial agglomeration's spatial pattern. Factor Analysis is used to identify the local economy's main factors, and Geographically Weighted Regression to identify how the factors determine the industrial agglomeration. The result shows LMIs in Semarang District geographically clustered, strongly agglomerated, and highly specialized in some subdistricts that occur in sub-sectors: food; beverages; wearing apparel; non-metal mining; and furniture Industry. The main factors of the local economy that determine the industrial agglomeration are: (1) factors of livestock and horticulture region positively affect the food industry agglomeration; and (2) factors of urban and industrial region positively affect to the wearing apparel industry agglomeration. The strong agglomeration and sectoral specialization reflect the spillover in the inter-firm relationship, employment opportunity, and knowledge transfer. The linkage of the food industry with the agriculture-based local economy (horticulture and livestock) illustrates the spatial integration and linkages between rural-urban areas. The linkage of the apparel industry that dominantly footloose with urban and industrial areas shows a great dependence on international markets and suppliers.
\end{abstract}

Copyright (C) 2019 GJGP-UNDIP This open access article is distributed under a Creative Commons Attribution (CC-BY-NC-SA) 4.0 International license.

How to cite (APA 6th Style):

Pangarso, R., Suharyadi, R., \& Rijanta, R. (2020). The Spatial Patterns and Local Economic Determinant of Industrial Agglomeration in Semarang District, Indonesia. Geoplanning: Journal of Geomatics and Planning, 6(2), 99-112. doi: 10.14710/geoplanning.6.2.99-112

\section{INTRODUCTION}

Indonesia's economic growth has been accompanied by rapid urbanization that has transformed Indonesian cities. The urbanization has progressed rapidly since the 1990s, and in 2015 about $67.5 \%$ of Indonesia's population lives in urban areas. Urbanization opens up opportunities to generate regional economic growth and encourage the formation of the metropolitan regions. Urbanization can drive productivity, economic opportunities, and increase income. Urban areas are generally economically more productive and competitive than rural due to positive externalities in the form of agglomeration. Urban areas create opportunities for the establishment of localization economies through the clustering of related activities. In contrast, urbanization economies may emerge in dense urban areas where the transaction cost of doing business is lower, and knowledge spillover opportunities are high. With the benefits of agglomeration, businesses within such economies tend to be more economically productive, as demonstrated by a faster rate of growth in GRDP than rural areas. The issue of urbanization and industrialization cannot be separated in the growth of cities in Indonesia (Bappenas, 2012). 
Industrialization is dominated by Large and Medium Industries (LMIs), which are significant in production and employment. Kuncoro (2002) identified LMI's agglomeration was concentrated in the metropolitan areas. Specialized LMIs generally have vertical relationships with global suppliers and access to international markets, and has better access to infrastructure (ports, arterial roads). The proximity of the geographical concentration of LMIs to urban areas aims to obtain urbanization economies, as demonstrated by the market size in urban areas.

Industrialization in Indonesia has been biased in LMIs and urban areas. On the other side, Small and Micro Industries (SMIs) is still become a 'marginal' player in the scheme of industrial development or only gets a small profit. In some industrial regions, poverty incidence has even emerged that showed poverty emerged along with the growth of modern industry (medium-large) because its local economic base did not grow and local communities were marginalized (Kuncoro, 2002; Muta'ali, 2011). The industrial agglomeration (dominated by LMIs) closely related to urbanization tends to grow rapidly by utilizing the benefits of agglomeration economies, but on the other hand, SMls generally still faces low productivity issues (Tambunan, 2011). Inward investments included in LMIs should impact job creation and encourage local businesses that are dominated by micro and small-scale businesses. Investment in a particular industrial sector should encourage the growth of related industries (Rostow \& Rostow, 1990; Ward et al., 2002).

Local economic development concerns in linkages, cooperation, or synergy among local economic actors. The linkage among the industrial sector with the local economy in order to increase the competitiveness of the local economy, as Porter (1990) argues that the local economy as the product of the competitiveness of the local economic actors such as local companies and local industries.

The research on the linkage of industrial agglomeration and the local economy in Semarang District focuses on economic actors (the business sector) related to the local economy. Semarang District was chosen as a research area because the region is growing significantly become the domination of urban areas toward a metropolitan region, namely Metropolitan Semarang, one of the economic development regions in Indonesia with a significant peri-urbanization (Firman, 1998; Bappenas, 2012). The manufacturing industry is the largest sector contributing to the district's GRDP reaching above $40 \%$. The region is also growing rapidly in urban areas, about $40 \%$ of its population lives in urban areas, thus showing the phenomena of industrialization and urbanization in the region. On the other side, the problem of unemployment and poverty still occurs despite the relatively large contribution, value-added, and industrial sector growth in the region. The unemployment rate in this region is still around $2.3 \%$ or 15,864 people and the poor population is still quite large, reaching 81,310 people or $8.5 \%$ (BPS Kabupaten Semarang, 2016). These phenomena show that people's income distribution in the region has not been equally realized.

Previous studies show that Semarang District, in general, is not supported by strong industrialization because of the domination of footloose industries in the region, which do not have strong forward and backward linkages with the region. The linkages of industrial and agricultural sectors are weak, indicating industrialization, which is expected to occur linkages, but leakages are happening in the region. The region only becomes the location of industrial activities and the weak linkages among the sectors cause significant benefits in the local economy (Wilonoyudho \& Keban, 2011; Hardati, 2014).

Some of the findings in this research show that industrial agglomeration in Semarang District is still dominated by the wearing apparel industry sub-sector, which tends to be located around urban and industrial areas, has a strong vertical relationship with foreign suppliers and international market access. Industrial agglomeration with the labor-intensive and footloose industry characteristics. But, the research also found the food industry sub-sector in the region has a strong relationship with the local economy that differs from previous studies by Wilonoyudho \& Keban (2011) and Hardati (2014). The food industry sub-sector establishes sectoral specialization at the local (sub-district) level and potentially forms industrial clusters. This sub-sector geographically tends to be located around the raw material area and has a strong linkage with the horticulture and livestock sub-sector or the agriculture sector, which is generally located in rural areas. 


\section{DATA AND METHODS}

The spatial pattern analysis of industrial agglomeration on 307 units of Large and Medium Industries (LMIs) consists of 66 large companies and 241 medium companies. The main factors analysis of the local economy and its effects on industrial agglomeration is carried out in the sub-district unit, in 19 sub-districts. The research flow chart can be seen in Figure 1. This research uses primary and secondary data for analysis. Primary data is the geographical coordinate data of the LMIs companies (307 units) were obtained by field mapping using GPS. Secondary data include: (1) LMIs data according to the industrial classification or industrial sub-sectors based on the Indonesian Standard of Industrial Classification (ISIC), the number of workers in each LMIs and data on types of investments, value of investments, and markets; (2) local economic conditions per sub-district include 102 variables; and (3) data on the characteristics of the study area. Secondary data was obtained through institutional surveys at the Cooperative, SMEs, Trade and Industry Agency; Statistic Agency (BPS); Planning Agency (BAPPEDA); and Investment and One-Stop Service Agency (DPMPTSP) of Semarang District.

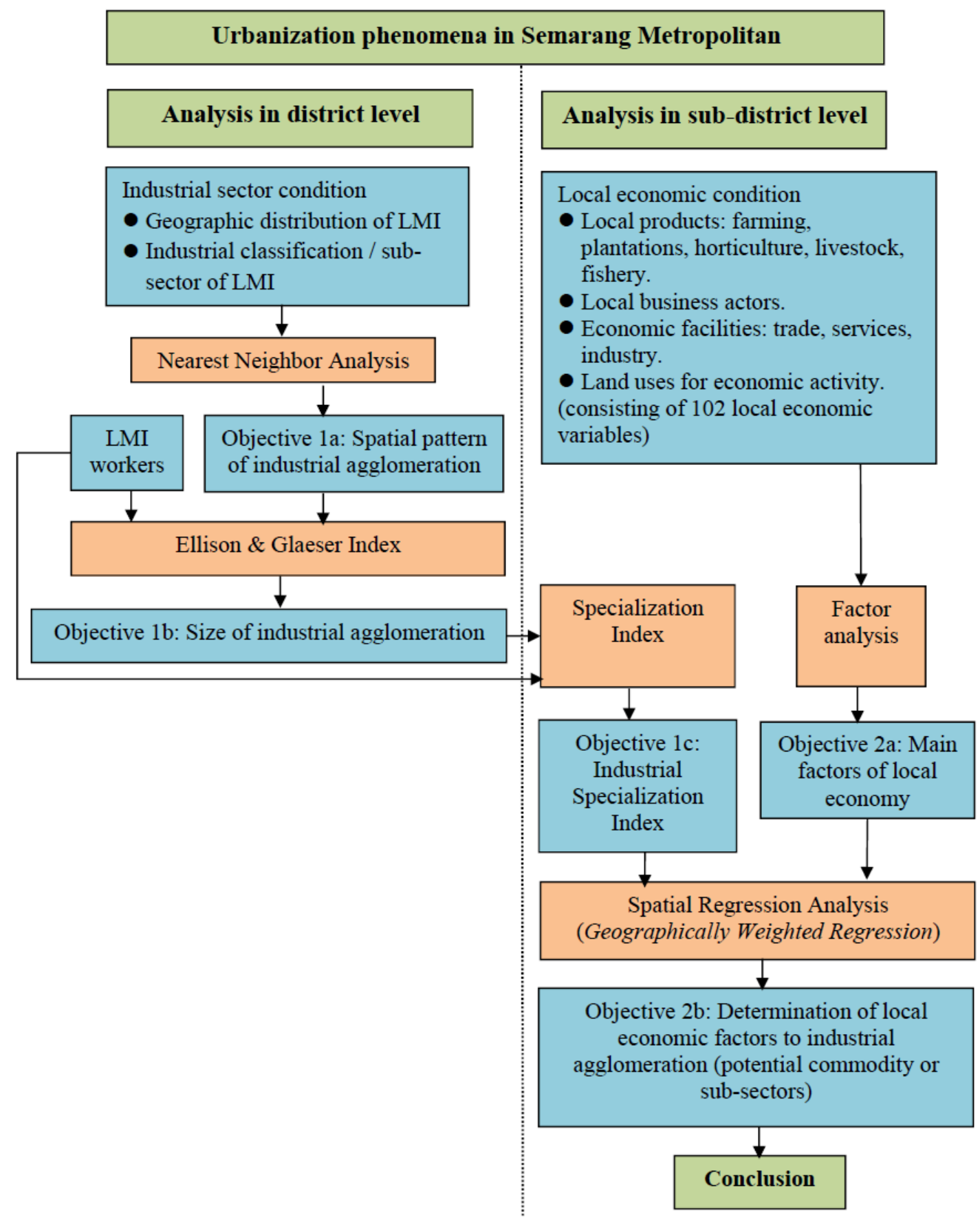

Figure 1. Research Flow Chart 
Spatial analysis of industrial agglomeration measures three variables: (1) industrial spatial distribution patterns (Yunus, 2010); (2) the scale of industrial agglomeration is measured by indicators of labor (Ellison \& Glaeser, 1997; Kuncoro, 2002; Ellison, Glaeser, \& Kerr, 2007); and specialization to measure the industrial concentration in the region (Porter, 1990; Kuncoro, 2002). Nearest Neighbor Analysis is used to analyze the spatial pattern of industrial agglomeration is the district level unit. The calculation results Nearest Neighbor Index (NNI) values that interpret to form a pattern: (1) clustered; (2) random; or (3) dispersed (O'Sullivan \& Unwin, 2010; Muta'Ali, 2015). Industrial agglomeration is shown by the NNI results that illustrate the clustered pattern of LMIs. The strength (size) of industrial agglomeration is measured by the Ellison and Glaeser Index or EG Index (Ellison \& Glaeser, 1997; Ellison et al., 2007). The EG Index calculation follows up on the NNI results, which shows certain industrial sub-sectors that are agglomerated by adding a number of workers variable. The unit of analysis of the Specialization Index is in the sub-district unit. High specialization in a certain industry will accelerate industrial growth (Kuncoro, 2002).

Factor analysis is used to determine the main factors in the local economy. Factor analysis in the research uses 102 local economic variables in units of sub-districts that describe local economic resources, types of business at the local level, and production of the main commodities of the local economy (Rustiadi, 2018; Ward et al., 2002). Spatial regression using Geographically Weighted Regression (GWR) is used to identify industrial agglomeration's determinant factors. GWR is a geographical or local regression that can explain the relationship between data variables spatially. The GWR method results in local models that vary for each location, thus differentiating it from global regression models (Fotheringham, Brunsdon, \& Charlton, 2000; Scott \& Janikas, 2010; Arsyadana, 2015).

The dependent variable $(Y)$ is the Specialization Index per industrial sub-sector, while the independent variable $(\mathrm{X})$ is the main factor of the local economy as a result of Factor Analysis. The unit of analysis in the Spatial Regression Analysis is at the sub-district level. There are five calculation of variable $Y$ : $Y 1=$ food industry specialization index; $\mathrm{Y} 2$ = beverage industry specialization index; $\mathrm{Y} 3=$ wearing apparel industry specialization index; $Y 4=$ non-metallic mineral industry specialization index; and $Y 5$ = furniture industry specialization index. The $X$ variable used in each calculation are: $X 1=$ factor score of livestock-associated with horticulture region; $X 2$ = factor score of horticultural region; $X 3=$ factor score of horticultural associated with plantations region; $X 4=$ factor score of plantation region; $X 5=$ factor score of plantation associated with livestock region; $\mathrm{X} 6$ = factor score of urban region; and $\mathrm{X} 7$ = factor score of industrial region.

\section{RESULT AND DISCUSSION}

\subsection{Spatial Pattern of Industrial Agglomeration}

The spatial distribution of the LMIs companies locations in Semarang District is illustrated in Figure 2. The spatial pattern analysis results with NNI show there are 10 of 21 sub-sectors of LMIs geographically form clustered patterns (see Table 1). The clustered patterns of LMIs means industrial agglomeration happened in the region. The EG Index calculation with the labor variable complements the result of NNI, which only uses geographical location variables. The results of the EG Index $(\Upsilon)$ calculation shows there are 5 of 10 LMIs subsectors in Semarang District most localized or agglomerated (see Table 1). 


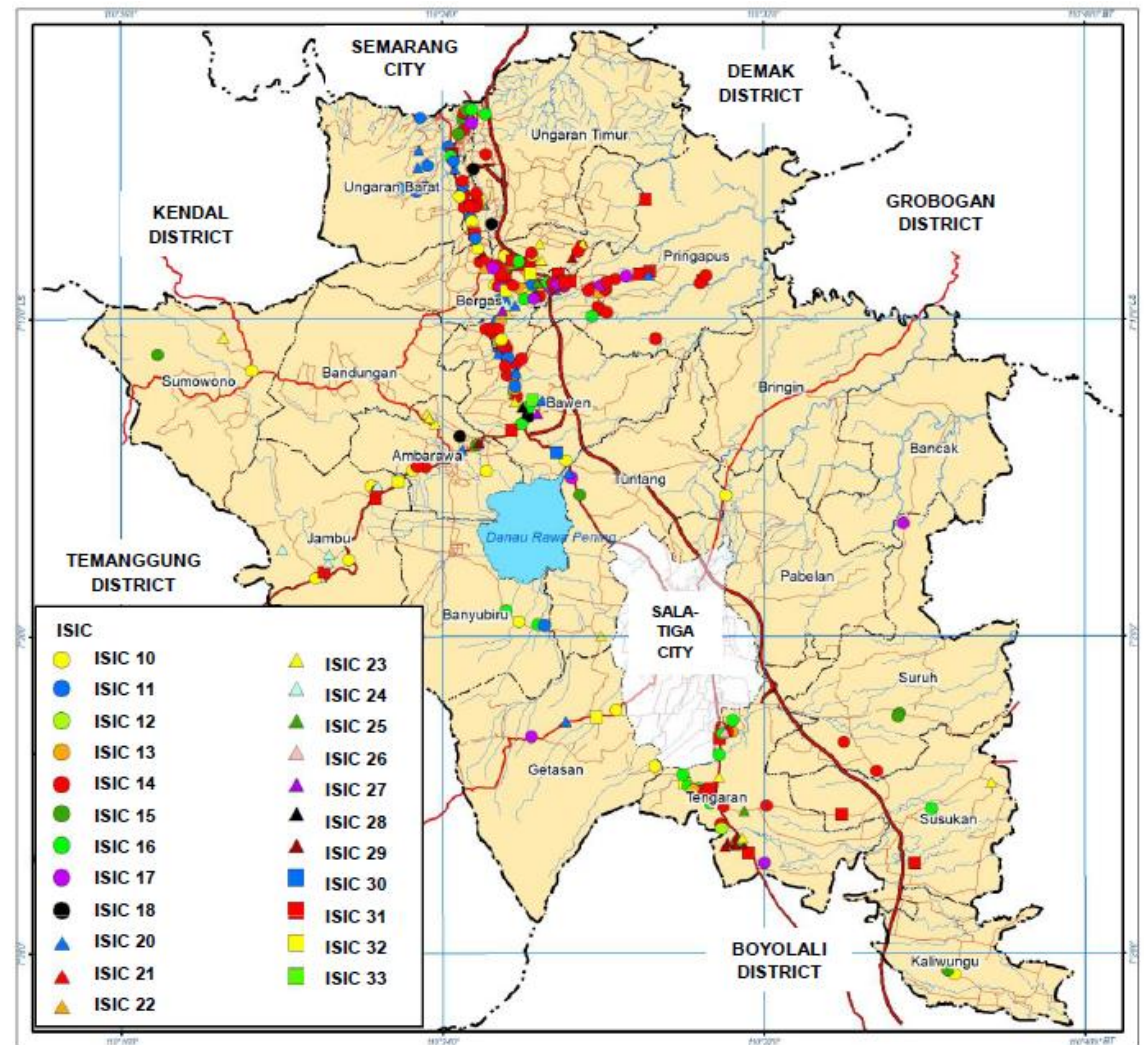

Figure 2. Spatial distribution of LMIs by sub-sector (ISIC) in Semarang District

The most localized industries in Semarang District are: (1) wearing the apparel industry; (2) food industry; (3) beverage industry; (4) furniture industry; and (5) non-metallic mineral product industry. The most localized agglomerated LMIs sub-sectors can be identified as having advantages and spillover, and potentially provide positive agglomeration externalities. The five most localized sub-sectors generate large workers: wearing the apparel industry $(79,805$ workers), food industry $(3,133$ workers), beverage industry (2,445 workers), furniture industry (2,693 workers), and non-metallic mineral products industry $(1,637$ workers). The five sub-sectors' total employment generation is 89,713 workers ( $72 \%$ of the total LMIs workers).

Table 1. Result of NNI and EG Index Calculation (Result of Analysis)

\begin{tabular}{|c|c|c|c|c|}
\hline \multirow[b]{2}{*}{ Sub-sector (ISIC two digit) } & \multicolumn{2}{|c|}{$\mathrm{NNI}$} & \multicolumn{2}{|c|}{ EG Index } \\
\hline & $\begin{array}{r}\mathrm{NN} \\
\text { Ratio }\end{array}$ & $\begin{array}{l}\text { Interpre- } \\
\text { tation }\end{array}$ & Y & $\begin{array}{l}\text { Interpre- } \\
\text { tation }\end{array}$ \\
\hline 1. Wearing apparel industry (ISIC-14) & 0.23 & Clustered & 2.53 & Most \\
\hline 2. Food industry (ISIC-10) & 0.82 & Clustered & 2.08 & localized \\
\hline 3. Beverage industry (ISIC-11) & 0.33 & Clustered & 0.30 & industries \\
\hline 4. Furniture industry (ISIC-31) & 0.58 & Clustered & 0.33 & \\
\hline 5. Non-metallic mineral products industry (ISIC-23) & 0.70 & Clustered & 0.26 & \\
\hline $\begin{array}{l}\text { 6. Wood and products of wood and cork, except } \\
\text { furniture, articles of straw, and plaiting materials } \\
\text { industry (ISIC-16) }\end{array}$ & 0.41 & Clustered & 0.12 & $\begin{array}{c}\text { Least } \\
\text { localized } \\
\text { industries }\end{array}$ \\
\hline $\begin{array}{l}\text { 7. Printing and reproduction of recorded media industry } \\
\text { (ISIC-18) }\end{array}$ & 0.37 & Clustered & -0.01 & \\
\hline 8. Chemicals and chemical products industry (ISIC-20) & 0.60 & Clustered & -0.15 & \\
\hline 9. Textile industry (ISIC-13) & 0.32 & Clustered & -0.28 & \\
\hline 10. Rubber, rubber goods, plastic industry (ISIC-22) & 0.18 & Clustered & 3.62 & \\
\hline
\end{tabular}
Note: ISIC = Indonesian Standard of Industrial Classification 
Industrial Specialization Index Analysis is carried out in more detail at the sub-district level, so it shows the character of the economic locality as a special sub-sector region. The LMIs Specialization Index calculation results show 14 of all 19 sub-districts in Semarang District are specialized regions in certain sub-sectors. The specialization region shows a comparative advantage over other districts. High specialization in a certain industry will accelerate the growth of the industry in the region. The spatial description of industrial agglomeration in the specialization regions can be seen in Table 2.

Table 2. Specialization region of LMls in Semarang District

\begin{tabular}{|c|c|c|}
\hline $\begin{array}{c}\text { Industrial Specialization } \\
\text { Region }\end{array}$ & Sub-district & Description of Spatial Pattern \\
\hline $\begin{array}{l}\text { 1. Specialization region of } \\
\text { the food industry (ISIC- } \\
\text { 10) }\end{array}$ & $\begin{array}{l}\text { Ambarawa, Bergas, } \\
\text { Getasan, Jambu, } \\
\text { Pringapus, Suruh } \\
\text { Sumowono, and East } \\
\text { Ungaran }\end{array}$ & $\begin{array}{l}\text { - Proximity some specialization regions to urban } \\
\text { areas due to market factors. } \\
\text { - Proximity some specialization regions to } \\
\text { agriculture and livestock areas as sources of } \\
\text { raw materials. Proximity to local commodities } \\
\text { potentially establishes industrial clusters. }\end{array}$ \\
\hline $\begin{array}{l}\text { 2. Specialization region of } \\
\text { the beverage industry } \\
\text { (ISIC-11) }\end{array}$ & $\begin{array}{l}\text { Bawen, Banyubiru, West } \\
\text { Ungaran, and East Ungaran }\end{array}$ & $\begin{array}{l}\text { Proximity specialization regions to the location of } \\
\text { water sources as the main raw material for } \\
\text { industry. The beverage industry does not create } \\
\text { significant value-added in the local economy. }\end{array}$ \\
\hline $\begin{array}{l}\text { 3. Specialization region of } \\
\text { wearing apparel industry } \\
\text { (ISIC-14) }\end{array}$ & $\begin{array}{l}\text { Bergas, Pringapus, and } \\
\text { West Ungaran }\end{array}$ & $\begin{array}{l}\text { Proximity specialization regions to the urban } \\
\text { areas and transportation infra-structure due to } \\
\text { import content, export orientation and labor } \\
\text { factors. Agglomeration creates positive } \\
\text { externalities in the interrelationship among } \\
\text { companies that potentially establish industrial } \\
\text { clusters. }\end{array}$ \\
\hline $\begin{array}{l}\text { 4. Specialization region of } \\
\text { non-metallic mineral } \\
\text { products industry (ISIC- } \\
\text { 23) }\end{array}$ & $\begin{array}{l}\text { Bergas, Ambarawa, } \\
\text { Sumowono, Tuntang and } \\
\text { Tengaran }\end{array}$ & $\begin{array}{l}\text { - Proximity some regions to urban areas and } \\
\text { infrastructure due to market factors } \\
\text { (construction). } \\
\text { - Proximity some regions to mining areas as } \\
\text { sources of raw materials but unsustainable in } \\
\text { the long term due to limited time to extract } \\
\text { mining. }\end{array}$ \\
\hline $\begin{array}{l}\text { 5. Specialization region of } \\
\text { furniture industry (ISIC- } \\
\text { 31) }\end{array}$ & $\begin{array}{l}\text { Pringapus, Tengaran, } \\
\text { Jambu, and Susukan }\end{array}$ & $\begin{array}{l}\text { - Proximity some regions to urban areas and } \\
\text { infrastructure due to export orientation and } \\
\text { outward materials. } \\
\text { - Proximity some regions to forestry and } \\
\text { plantations areas as sources of raw materials } \\
\text { (wood). }\end{array}$ \\
\hline
\end{tabular}

\subsection{Local Economic Factors Determinant of Industrial Agglomeration}

The main factors of the local economy in Semarang District are the results of factor analysis using 102 variables. Factor analysis results in 7 of 15 factors or components (with cumulative eigenvalues of $77.13 \%$ ). Then identification of the characteristic of the factor based on commodity categories or economic activities of the initial variables of analysis. The characteristic of a factor in line with the characteristics of the local economy at the sub-district level. The main factors of the local economy in Semarang District are: Factor 1 livestock associated with horticulture region; Factor 2 horticulture region; Factor 3 horticulture associated 
with plantations region; Factor 4 plantation region; Factor 5 plantations associated with livestock region; Factor 6 urban region; and Factor 7 industrial region. The factors in each sub-district have different strength levels indicated by the value of factor score.

The spatial regression analysis using GWR identifies how the local economic factors determine industrial agglomeration. Spatial regression analysis is carried out on five industrial sub-sectors that have sectoral specialization. The dependent variable $(\mathrm{Y})$ in the spatial regression analysis is the value of each LMIs subsector's specialization index in each sub-district. The explanatory variable $(X)$ in the analysis is the local economic factors in each sub-district. The results of the GWR analysis are described in Table 3.

Table 3. Indicators of GWR Model (Results of analysis using ArcGIS software)

\begin{tabular}{|c|c|c|c|c|}
\hline Sub-sector (ISIC two digit) & $\begin{array}{l}\text { Residual } \\
\text { Squares }\end{array}$ & $\mathrm{AlCc}$ & $\begin{array}{r}\text { Adjusted } \\
\mathrm{R}^{2}\end{array}$ & Interpretation \\
\hline 1. Food Industry (ISIC-10) & 522.65 & 154.92 & 0.54 & Significant (54\%)*) \\
\hline 2. Beverage industry (ISIC-11) & $1,208.92$ & 170.85 & -0.37 & Not Significant (37\%) \\
\hline 3. Wearing apparel industry (ISIC-14) & 1.01 & 36.19 & 0.57 & Significant $(57 \%) *$ ) \\
\hline $\begin{array}{l}\text { 4. Non-metallic mineral products industry } \\
\text { (ISIC-23 }\end{array}$ & 465.60 & 152.73 & 0.29 & Not Significant (29\%) \\
\hline 5. Furniture industry (ISIC-31) & 403.47 & 150.00 & -0.52 & Significant $(52 \%) *)$ \\
\hline
\end{tabular}

${ }^{*}$ ) The coefficient of determination or absolute value of adjusted $\mathrm{R}^{2}$ is significant if it is close to 1 or $100 \%$ (we consider significant if the absolute adjusted $R^{2}$ is above $50 \%$ )

The result of GWR shows a significant spatial regression model explains how much the independent variables together determine the sub-sectors: (1) food industry (adjusted R2 54\%); (2) wearing apparel industry (adjusted R2 57\%); and furniture industry (adjusted R2 52\%). The spatial regression model for other sub-sectors is considered not significant because the determination coefficient value is $\leq 50 \%$. The spatial regression method using GWR produces a different local model for each location that it differentiates with global regression. To find out the predictor variables (local economic factors), which significantly determine the response variable for each sub-district conducted t-test by calculating the value of $t$ ( $t$ count), namely the comparison between Estimated value with Standard Error in each variable for each sub-region, then the value of $t$ count compared to $t$ table. The $t$ count value greater than $t$ table shows significant variables in each subdistrict (see Table 4).

Table 4. Significant Local Economic Factors Determinant of LMIs Agglomeration (Result of Analysis)

\begin{tabular}{|c|c|c|c|}
\hline & $\begin{array}{l}\text { Sub-sector } \\
\text { (ISIC two digit) }\end{array}$ & Predictor variable & Location (Sub-district) \\
\hline \multirow[t]{4}{*}{1.} & \multirow[t]{4}{*}{$\begin{array}{l}\text { Food industry (ISIC- } \\
10)\end{array}$} & $\begin{array}{l}(+) X_{1} \text { (Livestock associated with } \\
\text { horticulture region) }\end{array}$ & All sub-district \\
\hline & & $(+) X_{2}$ (Horticulture region) & All sub-district \\
\hline & & $\begin{array}{l}\text { (-) } X_{3} \text { (Horticulture associ-ated } \\
\text { with plantations region) }\end{array}$ & All sub-district \\
\hline & & (-) $X_{7}$ (Industrial region). & $\begin{array}{l}\text { Ambarawa, Bancak, Bandungan, Ba-nyubiru, } \\
\text { Bawen, Bergas, Bringin, Kaliwungu, Pabelan, } \\
\text { Tuntang, Pring-apus, Sumowono, , West } \\
\text { Ungaran, East Ungaran }\end{array}$ \\
\hline \multirow[t]{2}{*}{2.} & Wearing apparel & $(+) X_{6}$ (Urban region) & All sub-district \\
\hline & industry (ISIC-14) & $(+) X_{7}$ (Industrial region) & All sub-district \\
\hline 3. & $\begin{array}{l}\text { Furniture industry } \\
\text { (ISIC-31) }\end{array}$ & No variable significant & All sub-district \\
\hline
\end{tabular}


The results of the spatial regression analysis showed that local economic factors significantly determine the LMIs agglomeration in two sub-sectors: (1) food industry; and (2) wearing the apparel industry, as the following explanation.

\subsubsection{Local Economic Factors Determinant of Industrial Agglomeration}

The livestock associated with the horticulture region (X1) and the horticultural region (X2) has a positive effect on the agglomeration of the food industry (see Figure 3 and Figure 4). The increase in local economic factors in the livestock and horticulture region is influenced by the increase in these commodities. The bigger production of livestock and horticultural commodities can increase the agglomeration of the food industry.

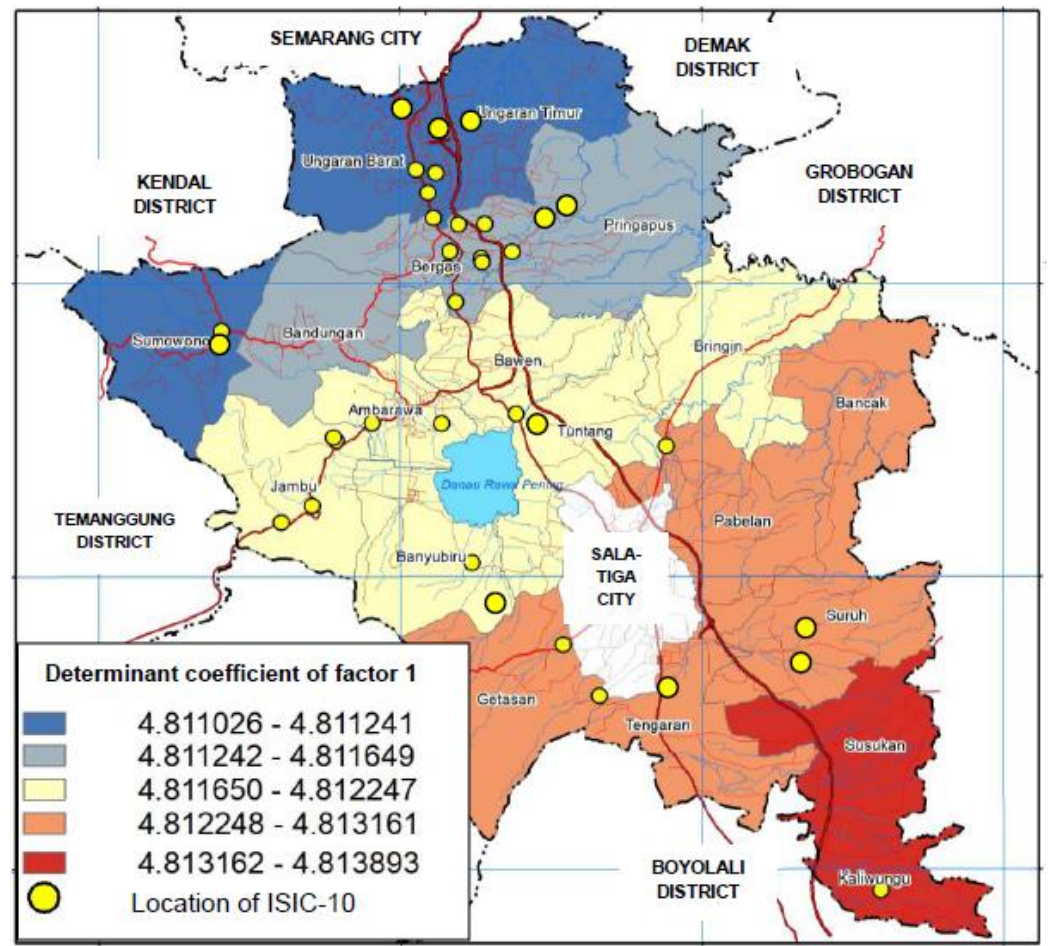

Figure 3. Results of GWR Analysis, the livestock-associated with horticulture region determinant of food industry agglomeration

The influence of local economic factors on food industry agglomeration can be seen in Getasan Subdistrict as a center of dairy milk production (production up to 20.7 million liters or $80 \%$ of total district production). 5 of 8 cooperatives/groups of dairy farmers/collectors in Semarang District are located in Getasan Sub-district. Companies in dairy milk processing are CV. Cita Nasional in Getasan Sub-district and PT. Cimory in Bergas Sub-district. 


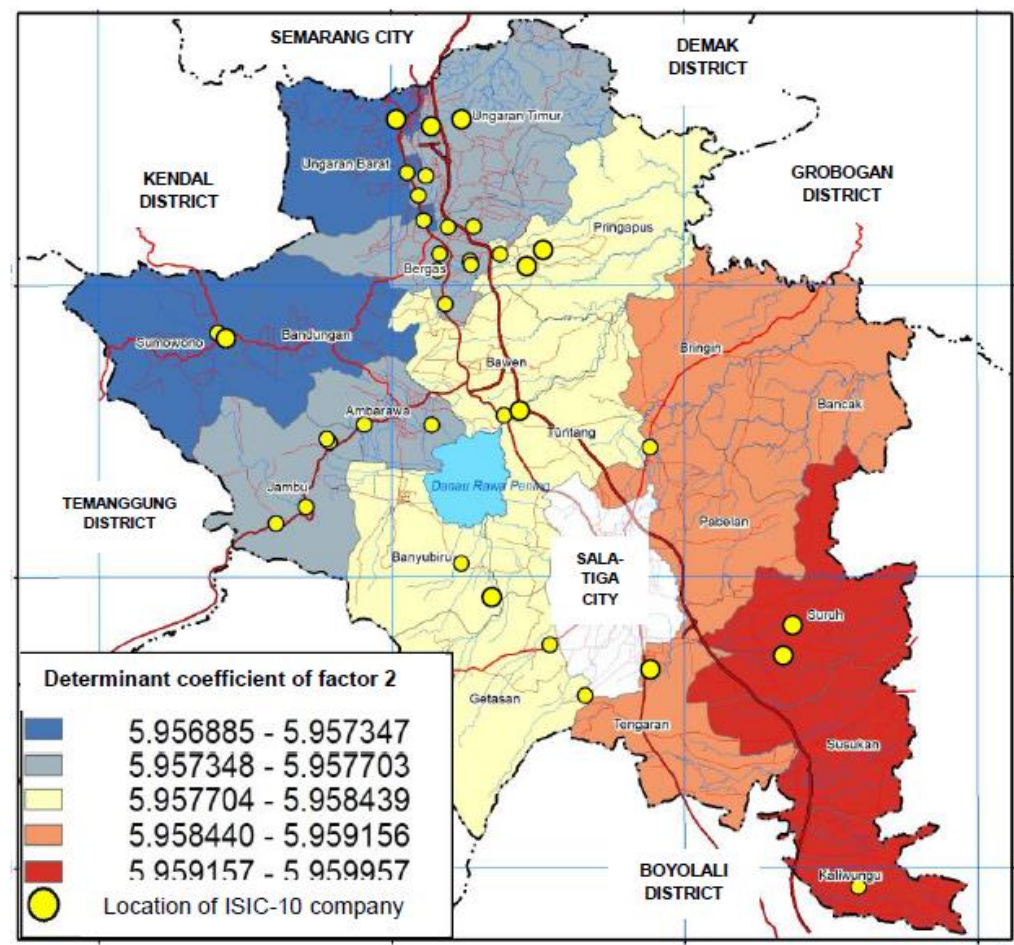

Figure 4. Results of GWR Analysis, the horticulture region determinant of food industry agglomeration

The food industry that produces meat/eggs product is related to livestock businesses in Semarang District. Producer of chicken products (fresh meat, sausage, and nugget) PT. Ciomas Adisatwa in Pabelan Subdistrict and CV. Indocipta Mitra Sejahtera in Getasan Sub-district) get the raw material from the surrounding area. Semarang District is a potential region of the livestock sub-sector, such as chickens, with total production up to 3,888 tons (BPS Kabupaten Semarang, 2016).

PT. Java Egg Specialties in Bergas Sub-district produces eggs and mayonnaise products get the supply of eggs from a group of farmers in Tuntang Sub-district, despite competing with egg suppliers from East Java Province. Eggs are a potential product in Semarang District, with production up to 228 million (BPS Kabupaten Semarang, 2016). The growth of the livestock sub-sector in the region encourages the breeding industry, PT. Japfa Comfeed Tbk. in Tengaran Sub-district, which produces DOC to supply farmers in the region and to other regions in Central Java Province.

Jambu, Banyubiru, Bandungan, Ambarawa, and Sumowono sub-districts are horticulture regions that produce commodities such as herbal plants, mushrooms, cassava, and yam to supply the raw materials for producers of herbal and food products such as UD Wijaya and UD Pertiwi in Jambu Sub-district, UD. Bumi Lestari in Sumowono Sub-district, and KUB Makmur Sentosa in Ambarawa Sub-district. The supply of raw materials of horticultural products also occurs across sub-districts, even across districts, as happened at PT. Sumber Boga Abadi and PT. Mangkok Mas in Bergas Sub-district.

\subsubsection{Local Economic Factors Determinant of Wearing Apparel Industrial Agglomeration}

The urban region (X6) and industrial region (X7) determine the wearing apparel industry agglomeration (see Figure 5 and Figure 6). This influence shows that the stronger the region's character as an urban and industrial area will increase the concentration of the wearing apparel industry. The proximity of industrial agglomeration to urban and industrial regions shows this sub-sector spatially depends on infrastructure, particularly transportation accessibility in an urban and industrial region. The infrastructure supports the accessibility of labor, raw materials, and product distribution.

The wearing apparel LMIs is the largest industrial sub-sector in Semarang District, consists of 87 companies and generates 79,805 workers ( 917 workers per company on average). It is categorized as a labor- 
intensive industry. The study results by Wijaya, Kurniawati, \& Hutama (2018) show that the labor-intensive industry in the region has attracted many migrant workers from other regions in Central Java Province. Daily workers' mobility or commuters and the growth of settlement areas around the industrial region become issues in Semarang District.

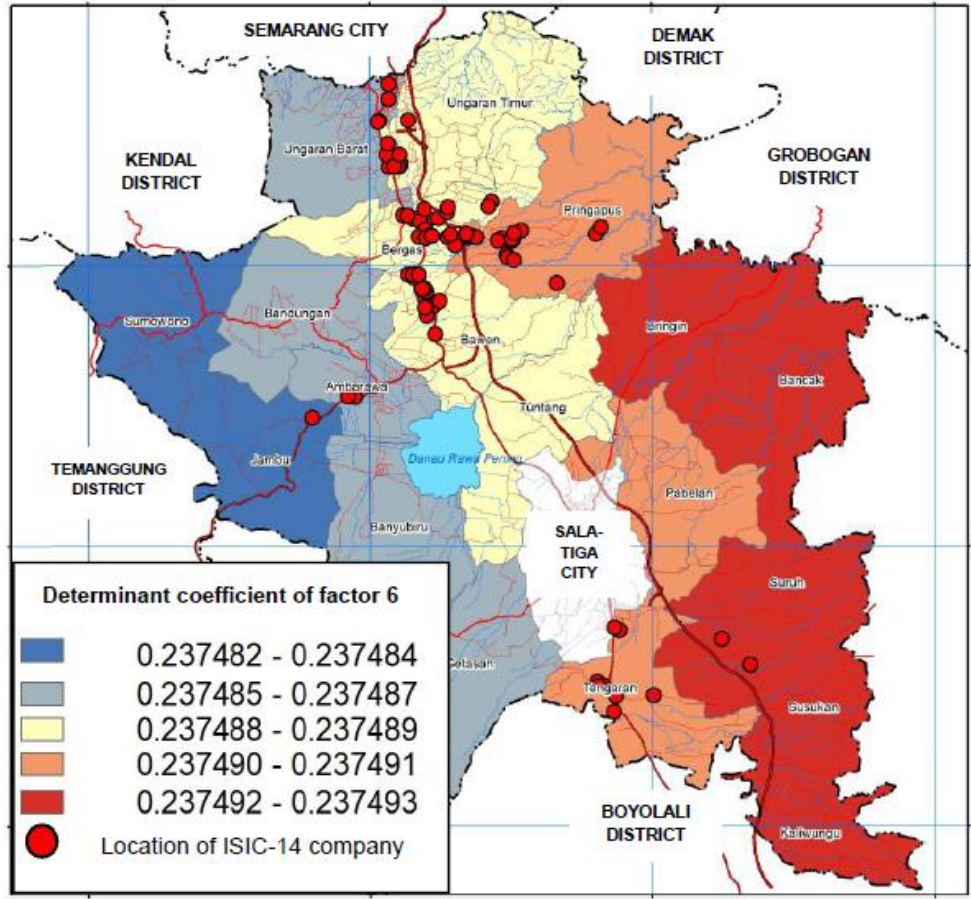

Figure 5. Results of GWR Analysis, the urban region determinant of wearing apparel industry agglomeration

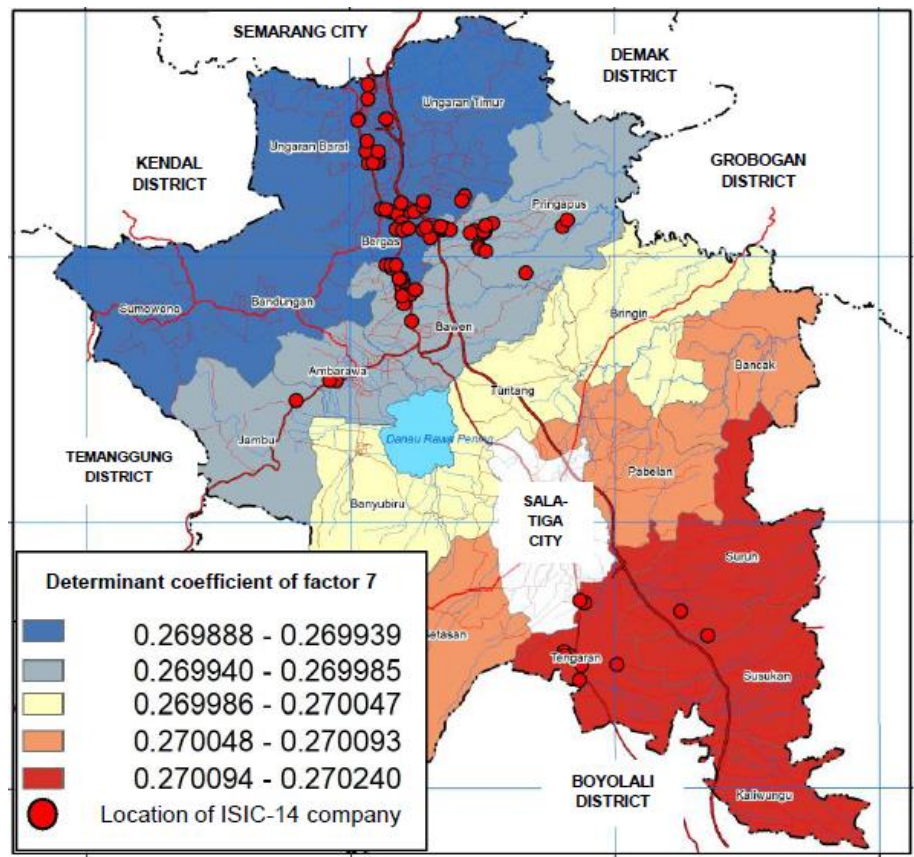

Figure 6. Results of GWR Analysis, the industrial region determinant of wearing apparel industry agglomeration 
Data from DPMPTSP of Semarang District in 2016 shows 57\% of wearing apparel LMls companies are Foreign Direct Investment (FDI) companies. 60\% of wearing apparel companies are located in industrial bonded zones. The high dependence on import-content materials in the wearing apparel industry agglomeration confirms the findings by Kuncoro (2002) that the LMIs agglomeration in the metropolitan area is associated with import content and export orientation. The concentration of FDI companies in Semarang Regency also tends to proximity to the same country of origin (for example, FDI companies from South Korea) that confirms the findings by Rofi (2015).

\section{CONCLUSION}

The spatial patterns of industries in Semarang District are geographically concentrated or clustered, which shows the phenomena of industrial agglomeration. The particular sub-sectors of the industry are strongly agglomerated. It reflects the interrelationship among companies (including business cooperation), the concentration of employment, and knowledge transfer that increase the positive externalities of industrial agglomeration. Industrial agglomeration also shows high sectoral specialization in certain sub-sectors that potentially establish industrial clusters, as occurred in the food industry and wearing the apparel industry. High specialization in a certain industry will accelerate the growth of the industry, that means potential industrial agglomerations will lead to positive externalities in the job opportunities, capital attractiveness, increased skills or knowledge, growth of related industries and services, and other functional relationships among industries, and improve regional competitiveness (Porter, 1990; Kuncoro, 2002; Fan \& Scott, 2003).

Certain sub-sectors of industry tend to be located around urban areas and infrastructure, which shows the proximity of industrial agglomeration to the population concentration to utilize urbanization externalities as reflected in market size in urban areas. Industrial agglomeration in metropolitan areas is influenced by import content, export orientation, labor, and better access to infrastructure (Kuncoro, 2002; Fujita, 2002; Qi, Fang, \& Song, 2008). Other sub-sectors such as the food industry that primary process products such as livestock products and plantations, the beverage industry, the wood industry, and the furniture industry geographically tend to be located around the raw material concentration. The proximity of industries to the raw material sources is in line with one of Marshall's industrial agglomeration theories that economically industrial locations consider the proximity to input suppliers to save transportation costs (Marshall Jr, Lynch, \& Smith, 1919).

The spatial regression model shows some local economic factors that significantly determine industrial agglomeration in Semarang District. It occurs in two sub-sectors: the food industry and the wearing apparel industry. The local economic factors of livestock and horticulture regions determine the industrial food agglomeration. Meanwhile, the local economic factors of urban and industrial regions determine the wearing apparel industrial agglomeration. The strong relationship of food industry agglomeration and horticultural and livestock region shows the proximity of industry to the source of raw materials. It means the proximity of food industry agglomeration to the rural areas. So the development of the food industry needs to be integrated with the rural economic development based on the agricultural sector (including the livestock and horticulture sub-sectors). In this context, industrial and agricultural development can be carried out within the rural diversification concept framework. This concept emphasizes the importance of non-agricultural employment opportunities and the increased income of rural households due to the relative increase in industrial and commercial activities related to agricultural activities (Rijanta, 2012). Rural industrialization is in line with the concept of spatial integration in rural-urban linkages as mutually relationships in the term of economic linkages (Rondinelli, 1985; Douglass, 1998).

The finding that the food industry sub-sector in Semarang District has a strong relationship with the local economy differs from previous studies (Wilonoyudho \& Keban, 2011; Hardati, 2014) because of the different methods and variables used. The study by Wilonoyudho \& Keban (2011) used descriptive analysis, focus group discussion, interviews, and observations, not specifically examining spatial determinants of industry. A study by Hardati (2014) used the variables of agriculture and non-agriculture sectors in spatial analysis. In contrast, our study based on the geographical distribution of industries and employment is classified in subsectors and uses spatial statistical analysis techniques. 
The relationship of urban region and the wearing apparel industrial agglomeration is in line with literature on the positive correlation between industrial agglomeration and urban agglomeration (Kuncoro, 2002; Fujita, 2002; Qi, Fang, \& Song, 2008). Our findings that show the industrial region determine the wearing apparel industrial agglomeration, particularly in the peri-urban, confirms the study by Kuncoro (2002), Fan \& Scott (2003), and Rofi (2015). This phenomenon shows industrialization and urbanization issues cannot be separated in urban development, including in Semarang District.

The inter-sectoral linkages in the wearing apparel industry are not significant compared to the food industry because most wearing apparel companies in Semarang District are categorized as the footloose industry. The footloose industry relies heavily on imported raw materials, export markets, and works within bonded zones. However, there are other business activities related to suppliers or service providers for LMIs wearing apparel (embroidery, fabric printing, packaging, and other subcontracts) and utilization of wearing apparel production waste by SIs to produce various goods (mattresses, doormats, and household appliances). Those businesses economically are not significant compared to the value of the LMIs wearing apparel.

The spillover impact of the wearing apparel industry sub-sector mainly occurs in the concentration of employment and knowledge or skills transfer. The wearing apparel sub-sector in Semarang District mostly labor-intensive industry which attract large migrant workers (around 50\%) from other regions in Central Java Province even outside the province, resulting in highly inter-regional labor mobility. This finding is in line with the study by Bartik (1991) that high inter-regional labor mobility causes an increase in labor demand, which will be followed by an increase in labor supply from other regions, so that the industrial sub-sector is not optimal in reducing unemployment at the local level in the long run. Spillover in knowledge and skills transfer of in the field of wearing apparel encourages the growth of small scale similar businesses, although not economically significant. High inter-regional labor mobility causes transportation problems and some migrant workers who settle around industrial areas triggering land use changes in the region. Labor is a major issue in the wearing apparel industry sub-sector.

This study concludes that industrial agglomeration in Semarang District, as part of the metropolitan area, is still dominated by the wearing apparel industry sub-sector, which tends to be located around urban and industrial areas, has a strong vertical relationship with foreign suppliers and international market access. Industrial agglomeration with the labor-intensive and footloose industry characteristics explains the dependency theory that metropolitan cities in developing countries have a high dependence on the economic system of developed countries. High dependence in terms of supply and international markets in the long term can lead to inequality, including inequality in urban and rural areas (Myrdal, 1968; Rustiadi, 2018).

Industrial agglomeration in certain sub-sectors in Semarang District, such as the food industry sub-sector, establishes sectoral specialization at the local (sub-district) level and potentially to form industrial clusters. This sub-sector geographically tends to be located around the raw material area and has a strong linkage with the horticulture and livestock sub-sector or the agriculture sector, which is generally located in rural areas. Food industry agglomeration encourages spatial integration or linkages between rural and urban areas (rural-urban linkage) can explain the interdependency theory, which bridges the modernization theory and dependency theory by reducing the gap between regions. An approach to the interdependency theory focuses on developing regional networks based on the clustering model by providing opportunities for the development of local economic factors (endowment) in a region. The development of small towns in periphery regions or rural areas can counterbalance the tendency of over-urbanization in the metropolitan area (Rondinelli, 1985; Douglass, 1998; Rustiadi, 2018).

The theoretical implications in the scientific field of geography and regional development and policy implications based on the study results can be input for regional development, particularly in Semarang District as follows.

1. The linkage of industrial agglomeration and the local economy in the metropolitan region can complement the concept of spatial integration or rural-urban linkages (Rondinelli, 1985; Douglass, 1998). The spatial linkage that works in peri-urban and rural areas can be a counterbalance to the tendency of over-urbanization in metropolitan areas (Friedmann, 1992; McGee, 1994; Firman, 1998; Rustiadi, 2018; Wilonoyudho \& Keban, 2011). 
2. The linkage of industrial agglomeration and a local economy based on cluster model opens up opportunities for the development of local economic endowment factors in a region (Porter, 1990), so that further studies on cluster dynamics are suggested, particularly in the prospective commodities of Food Industry sub-sector (e.g., cow milk processing, meat, and egg processing, or horticulture products processing).

3. The Food Industry sub-sector, which processes local agriculture products (horticulture and livestock) potentially to be developed in rural and peri-urban areas, therefore it is recommended to develop competitive and industry-oriented local agricultural commodities, such as dairy milk, beef, chicken, eggs, fruits, vegetables, and herbs. In the other side, the industrial sector development needs to be focused on the investment of industries that functionally related with the local economy.

4. Spatial linkage in the form of spatial integration requires reliable regional infrastructure, particularly to improve the accessibility of rural and urban areas, so that it is necessary to improve the transportation network system among sub-districts as well as regional economic zones.

\section{REFERENCES}

Arsyadana, H. H. (2015). Perbandingan Regresi Global dan Geographycal Weighted Regression (GWR) pada Model Kasus Prevalensi Penyakit Hepatitis. Jurnal Statistika Universitas Muhammadiyah Semarang, 3(2).

Badan Pusat Statistik Kabupaten Semarang. (2016). Statistik Daerah Kabupaten Semarang Tahun 2016.

Bappenas. (2012). Indonesia - The Rise of Metropolitan Regions: Towards Inclusive and Sustainable Regional Development. Jakarta.

Bartik, T. J. (1991). Who benefits from state and local economic development policies? [Crossref]

Douglass, M. (1998). A Regional Network Strategy for Reciprocal Rural-Urban Linkages : An Agenda for Policy Research with Reference to Indonesia. Third World Planning Review, 20(February 1998). [Crossref]

Ellison, G., Glaeser, E., \& Kerr, W. (2007). What Causes Industry Agglomeration? Evidence from Coagglomeration Patterns, Harvard Institute of Economic Research. [Crossref]

Ellison, G., \& Glaeser, E. L. (1997). Geographic concentration in US manufacturing industries: a dartboard approach. Journal of Political Economy, 105(5), 889-927. [Crossref]

Fan, C. C., \& Scott, A. J. (2003). Industrial agglomeration and development: a survey of spatial economic issues in East Asia and a statistical analysis of Chinese regions. Economic Geography, 79(3), 295-319. [Crossref]

Firman, T. (1998). The Patterns of Indonesia's Urbanization, 1980-2007. The Dynamics of Indonesia" $S$ Urbanization, 2006, 1-31.

Fotheringham, A. S., Brunsdon, C., \& Charlton, M. (2000). Quantitative geography: perspectives on spatial data analysis. Sage.

Friedmann, J., \& others. (1992). Empowerment: The politics of alternative development. Blackwell.

Fujita, M. (2002). Economics of Agglomeration: Cities, Industrial Location, and Regional Growth. Cambridge University Press.

Hardati, P. (2014). Pola Keruangan Keterkaitan Sektor Pertanian dengan Non-pertanian dan Konsekuensinya pada Strategi Penghidupan Rumahtangga di Kabupaten Semarang. Unpublished Ph. D. Dissertation. Universitas Gadjah Mada. Yogykarta.

Kuncoro, M. (2002). Studi Aglomerasi dan Klaster Industri Indonesia. Yogyakarta: UPP-AMP YKPN.

Marshall Jr, E. K., Lynch, V., \& Smith, H. W. (1919). On dichlorethylsulphide (mustard gas) II. Variations in susceptibility of the skin to dichlorethylsulphide. J Pharm Exp Therap, 12, 291-301.

McGee, T. G. (1994). Labour force change and mobility in the extended metropolitan regions of Asia. $R J$ Fuchs, \& E. Al, Mega-City Growth and the Future, 62-93.

Muta'ali, L. (2011). Kapita selekta pengembangan wilayah. Badan Penerbit Fakultas Geografi, Universitas Gadjah Mada.

Muta'ali, L. (2015). Teknik Analisis Regional untuk perencanaan wilayah, tata ruang dan lingkungan. Yogyakarta: Badan Penerbit Fakultas Geografi Universitas Gadjah Mada, 347.

Myrdal, G. (1968). Teoria econômica das regiões. Saga. 
O’Sullivan, D., \& Unwin, D. J. (2010). Geographic information analysis and spatial data. Geographic Information Analysis, 1-32. [Crossref]

Porter, E. (1990). The Competitive Advantage of Nations. Harvard Business Review, 68, 73-93.

Qi, W., Fang, C., \& Song, J. (2008). Measurement and spatial distribution of urban agglomeration industrial compactness in China. Chinese Geographical Science, 18(4), 291-299. [Crossref]

Rijanta, R. (2012). Geographical Perspectives on Rural Diversification. Badan Penerbit Fakultas Geografi, Universitas Gadjah Mada.

Rofi, A. (2015). Perusahaan Asing Sektor Manufaktur di Indonesia: Dinamika Spasial Industri dan Keputusan Lokasi Industri. Gadjah Mada University.

Rondinelli, D. A. (1985). Population distribution and economic development in Africa: the need for urbanization policies. Population Research and Policy Review, 4(2), 173-196. [Crossref]

Rostow, W. W., \& Rostow, W. W. (1990). The stages of economic growth: A non-communist manifesto. Cambridge university press.

Rustiadi, E. (2018). Perencanaan dan pengembangan wilayah. Yayasan Pustaka Obor Indonesia.

Scott, L. M., \& Janikas, M. V. (2010). Spatial statistics in ArcGIS. In Handbook of applied spatial analysis (pp. 27-41). Springer.

Tambunan, T. (2011). The Impacts of Trade liberalization on Indonesian small and medium-sized enterprises. TKN Policy Paper. International Institute for Sustainable Development, Manitoba.

Ward, B., Lewis, J., Britain, G., \& Unit, N. R. (2002). Plugging the Leaks: Making the most of every pound that enters your local economy. New Economics Foundation London.

Wijaya, H. B., Kurniawati, H., \& Hutama, S. (2018). Industrialization Impact on Worker Mobility and Land Use in Peri Urban Area (Case study of Semarang District, Indonesia). IOP Conference Series: Earth and Environmental Science, 123, 12037. [Crossref]

Wilonoyudho, S., \& Keban, Y. T. (2011). Determinan dan Dampak Urbanisasi Berlebih di Kota Semarang. [Yogyakarta]: Universitas Gadjah Mada.

Yunus, H. S. (2010). Metodologi penelitian wilayah kontemporer. Yogyakarta: Pustaka Pelajar. 